\title{
The Development of Attitudes and Professional Skills of ECE Teachers Field Introduction Activities
}

\author{
Anita Yus ${ }^{1, *}$ Peny Husna Handayani ${ }^{2}$ Dwi Septi Anjas Wulan ${ }^{3}$ Artha Mahindra \\ Diputera $^{4}$ \\ 1,2,3,4 Universitas Negeri Medan \\ *Corresponding author. Email: anitayus.dikdas@gmail.com
}

\begin{abstract}
Candidates for early childhood education teachers need to have a number of competencies that demonstrate the professionalism of early childhood education teachers. Efforts to help undergraduate students of early childhood education teacher education have the ability to develop a professional attitude are provided by learning programs including the school field introduction program $(S F I)$. The general objectives of this study are to describe, 1) the competence of attitudes and professional skills that early childhood education teachers need to have; 2) the commitment of PGPAUD students to develop professional attitudes and skills that teachers in early childhood education need to have; and 3) students' perceptions of the school field introduction program. This research was conducted using descriptive quantitative research with a sample of 64 students of undergraduate education teacher education for early childhood education at the Universitas Negeri Medan, Faculty of Education. Data was collected using a questionnaire and followed interview by focus group discussion. Data were analyzed by descriptive statistics which were complemented by qualitative analysis. The results obtained indicate that: 1) the competence of attitudes and professional skills that early childhood education teachers need to have consists of seven dimensions of professionalism whose descriptions are 120 indicators, 2) $92 \%$ of PGPAUD undergraduate students have a high commitment to developing the attitudes and professional skills of PAUD teachers through the (SFI) program, and 3) $88 \%$ of undergraduate students in early childhood education teacher education have a good perception of the school field introduction program they have undertaken. The results of this study are expected to be used as study material in developing a school field introduction program and an attitude and professionalism development program for early childhood education teachers as a whole.
\end{abstract}

Keywords: Early childhood education teachers, Professionalism, Indicators of early childhood education teachers professionalism, and School field introduction programs.

\section{INTRODUCTION}

Teachers and the community already have an understanding that to become a teacher it is necessary to have certain qualifications and competencies. In Indonesia, the obligation to have qualifications and competence as a teacher already has a legal umbrella. The descriptions of both are listed in the National Education System Law Number 20 of 2003 and Law Number 14 of 2005 concerning Teachers and Lecturers. Qualifications indicate a formal educational background and competencies indicate the abilities that teachers need to have. Qualifications and competencies are obtained from educational personnel education institutions.

Educational personnel education institutions provide a number of learning experiences so that students have a number of competencies as subject learning outcomes (LO) for each course. After the number of learning outcomes required at one level have been met, students will gain qualifications, such as a bachelor's degree in education or teacher candidates with a bachelor's degree in education (S1). There are several learning experiences, such as face-to-face lectures, seminars, and field observations. One of the programs that students need to follow is the school field introduction program (SFI).

The SFI program provides opportunities for undergraduate education students (undergraduate education programs) to gain experience related to schooling (Permenristekdikti Nomor 55 tahun 2017). Through this SFI program, students are expected to gain a number of learning experiences that shape competencies related to the management and administration of schools, the duties and responsibilities of teachers. These learning experiences are expected to build the competency construct of teacher professionalism, including the professionalism of PAUD teachers. There are four aspects of competence that need to be developed by PAUD teachers, namely pedagogic, 
professional, social and personality competencies. Each aspect has a number of indicators [1]. These four competencies will affect teacher performance [2]

Personality competence includes the ability to behave and behave in accordance with the psychological needs of the child. Able to present oneself as a person of noble character. This behavior is related to behavior that makes other people feel safe, comfortable. These behaviors include loving children sincerely, being patient, calm, cheerful, and caring; Sensitivity, responsiveness and humor to children's behavior.

Professional competence is related to the ability to understand the stages of child development, child growth and development, the ability to provide educational stimulation, care and protection, and the ability to build cooperation with parents in the education, care and protection of children. In addition, this competence is shown in the form of the ability of educators to understand the continuity of the level of development of children aged 0-6 years; understand the standard level of achievement of child development, and be able to communicate the programs of development and care institutions to parents and increase parental involvement in programs at PAUD institutions.

Pedagogic competence is related to the ability to plan activities for education, care and protection programs, carry out processes and carry out assessments of the processes and outcomes of education, care and protection. This ability is demonstrated by the teacher in the form of the educator's ability to plan annual, semiannual, monthly, weekly and daily activities; establish play activities that support the level of achievement of children's development; carry out assessment activities in accordance with predetermined methods; manage the results of the assessment; use the results of the assessment for various educational purposes; document the results of the assessment.

Social competence is the teacher's ability to adapt to the environment and communicate effectively with students and parents. This competence is demonstrated through the ability of educators to adapt to peers, adjust to the surrounding community, accommodate students, parents, peers from various cultural and socio-economic backgrounds, communicate empathically with parents of students; and communicate effectively with students, both physically, verbally and nonverbally. The competencies possessed by the teacher will affect the teacher's performance, namely, beliefs and values; Skills; experience; personality characteristics; emotional problems; and intellectual ability [3]; [4].

The implementation of SFI courses is carried out with the principle of coherence between curriculum components. Coherence in the content of the teacher education curriculum means that there is a link between groups of subjects in the field of study (content knowledge), groups of subjects related to knowledge of general pedagogical knowledge that applies to all specific fields of study (content specific pedagogical knowledge), knowledge and skills in curriculum development (curricular knowledge), knowledge and skills in the selection and development of assessment tools (assessment and evaluation), and knowledge of educational contexts.

SFI is expected to be able to develop a mental attitude in the form of commitment from students as prospective members of the profession to always realize and improve their professional quality [5]. The professional competence of ECE teachers who are ready to be further developed and improved through the professional education program. Commitment is expressed as an engagement often without a written agreement. Everyone is required to have a high commitment to their professional duties. With this commitment, a person will try to do the best for his profession [6]. If teachers have a commitment to develop self-competence continuously, then the processes of planning, developing, implementing, managing, and evaluating learning programs are believed to be able to be carried out in accordance with current demands.

Professionalism is a term that refers to a mental attitude in the form of commitment from members of a profession to always realize and improve their professional quality [7];[5]. The quality of one's professionalism is supported by several competencies, namely 1) the desire to always display behavior that is close to the ideal standard, 2) always improve and maintain the professional image, 3) always pursue professional development opportunities that can improve and improve the quality of knowledge and skills, 4) pursue quality and ideals in the profession [5]. Thus, the professionalism of early childhood educators is the attitude of early childhood educators who seek to improve their abilities professionally in educating early childhood.

The competencies and indicators of ECE teachers that have been stated in the previous section are related to the seven dimensions of teacher professional competence proposed Brock [8], and this is closely related to how students perceive professional development activities [9]. The competencies possessed by ECE teachers must at least comply with applicable standards [10]; [11]; [12]. Some of the teachers in the field turned out to be still lacking, so there was not enough time to improve competence [13].

\section{METHOD}

This research is a field research using quantitative methods. The data were analyzed using quantitative descriptive analysis techniques and equipped with qualitative descriptive analysis, especially on data 
analysis of policy and curriculum documents. The population of this research is undergraduate students from the department of early childhood teacher education, Faculty of Education, State University of Medan who have completed SFI 1 and will do SFI 2 in the following semester. The entire population was used as a research sample of 64 people. Data were collected using a questionnaire followed by interviews and focus group discussions. The data were analyzed by using percentage analysis technique to see how likely it was that there was a scatter of data based on the specified categories.

Table 1. Categories and Scores of Perceptions of SFI and Student Commitment to Improve Professionalism

Category

Score

\begin{tabular}{|l|c|}
\hline Very Good & 4 \\
\hline Good & 3 \\
\hline Pretty Good & 2 \\
\hline Deficient & 1 \\
\hline
\end{tabular}

(Sugiono, 2009)

\section{RESULT AND DISCUSSION}

The results of data analysis show the following research results:

\subsection{The competence of attitudes and} professional skills that early childhood education teachers need to have

The search on the dimensions and indicators of the attitudes and skills of teachers' professionalism was developed based on the results of the study of the dimensions and indicators proposed by Brock [8] and Permendikbud Nomor 137 concerning Standards for the Implementation of ECE based on the results of the qualitative analysis, it was formulated that the dimensions of attitude and professionalism skills consist of seven dimensions [9]; [14]; [15]. In full, the seven dimensions of attitudes and skills of ECE teacher professionalism are presented in Table 2 below.

Table 2. Distribution of Items on Each Dimension of Professionalism

\section{NO DIMENSIONS NUMBER ACVERAGE OF SCORE POINT}

\begin{tabular}{c|l|c|c}
\hline $\mathbf{1}$ & Values & 9 & 3,1 \\
\hline $\mathbf{2}$ & Etics & 9 & 3,1 \\
\hline $\mathbf{3}$ & Autonomy & 7 & 2,9 \\
\hline $\mathbf{4}$ & Knowledge & 12 & 3,3 \\
\hline $\mathbf{5}$ & Skills & 15 & 3,4 \\
\hline
\end{tabular}

\begin{tabular}{c|l|c|c}
\hline $\mathbf{6}$ & Awards & 9 & 3,0 \\
\hline $\mathbf{7}$ & $\begin{array}{l}\text { Education and } \\
\text { Training }\end{array}$ & 14 & 3,1 \\
\hline & total & $\mathbf{7 5}$ & $\mathbf{3 , 1 3}$ \\
\hline
\end{tabular}

Table 2 shows that the items in each dimension are approved as an indicator of competence and the skill dimension has the highest average score as an indicator of teacher competence even though it is still in the agreed category. Dimensions of skills to perform the tasks of the ECE teacher profession have the highest average score. Skills in carrying out tasks have a significant effect on performance [16] even on work quality [17].

\subsection{The commitment of PGPAUD students to develop professional attitudes and skills that teachers in early childhood education need to have}

Commitment is defined as an attachment to the profession that will be undertaken. The results of the analysis show that the commitment scores to the SFI program obtained by students are in the good category. When explored further, it is known that there are aspects of commitment shown in the statement items that tend to be small. This is shown in the items of learning load, which is 174 with the category of not agreeing. There are still students who agree with the statement that the learning load in the SFI program burdens students. This finding needs to be studied further by analyzing the elements of commitment [14], such as maybe students are committed because they love the ECE teaching profession or because they are afraid of losing the opportunity to get good grades. This commitment will have an impact on the quality of activities during SFI [18]; [19].

Table 3. Description of Scores and Categories of Student Commitment to The Implementation of SFI

\begin{tabular}{c|l|c|l} 
No. & \multicolumn{1}{c}{ Statement } & Score & Category \\
\hline $\mathbf{1}$ & $\begin{array}{l}\text { The purpose of SFI } \\
\text { has not fully } \\
\text { described the } \\
\text { formation of teacher } \\
\text { professionalism }\end{array}$ & 235 & Agree \\
\hline $\mathbf{2}$ & $\begin{array}{l}\text { The scope of SFI is } \\
\text { too broad }\end{array}$ & 245 & Agree \\
\hline $\mathbf{3}$ & $\begin{array}{l}\text { The formulation of } \\
\text { graduate learning } \\
\text { outcomes (LO) is } \\
\text { very easy for } \\
\text { students to achieve }\end{array}$ & 261 & Agree \\
\hline $\mathbf{4}$ & $\begin{array}{l}\text { The learning load } \\
\text { given in this SFI } \\
\text { program is }\end{array}$ & 174 & $\begin{array}{l}\text { Don't } \\
\text { Agree }\end{array}$ \\
\hline
\end{tabular}




\begin{tabular}{|c|l|l|l}
\hline & $\begin{array}{l}\text { burdensome for } \\
\text { students }\end{array}$ & & \\
\hline $\mathbf{5}$ & $\begin{array}{l}\text { The learning load } \\
\text { given in the SFI } \\
\text { program has not } \\
\text { been able to help } \\
\text { students achieve } \\
\text { graduate learning } \\
\text { outcomes }\end{array}$ & 203 & $\begin{array}{l}\text { Don't } \\
\text { Agree }\end{array}$ \\
\hline $\mathbf{6}$ & $\begin{array}{l}\text { Requirements to } \\
\text { become a SFI } \\
\text { student can be met } \\
\text { by students }\end{array}$ & 297 & $\begin{array}{l}\text { Strongly } \\
\text { Agree }\end{array}$ \\
\hline
\end{tabular}

\subsection{The students' Perceptions of the School Field Introduction program}

The quality of student perceptions of the SFI program is described in four categories, namely very good, good, sufficient and poor. There are no students who have a perception that the SFI program is in the less category. The number of students who have a perception of the SFI program is in the very good very small category, which is $6 \%$. Generally $(88 \%)$ students have a perception of the SFI program in the good category. The results of the analysis covering four aspects are presented in Figure 1.

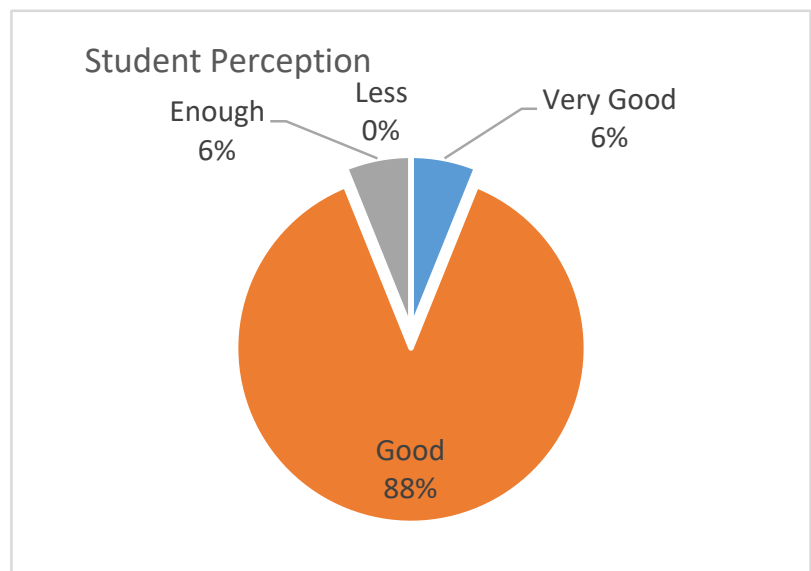

Figure 1. Graph of students' perceptions of the sfi program

This good perception still needs to be improved because there is still one category above it and those who have a less category is still 6\%. When explored in more detail, it is known that aspects that need to be clarified so that students have a good perception of the sfi program are aspects related to the mentoring system and assessment system including the worksheets used by students in sfi. The results of the complete analysis are presented in table 4 below.
Table 4. The aspects of scores and categories students perceptions of the SFI program

\begin{tabular}{|c|c|c|c|}
\hline No. & Statement & Score & Category \\
\hline 1 & $\begin{array}{l}\text { I already have an } \\
\text { understanding of what } \\
\text { the School Field } \\
\text { Experience Program } \\
\text { (SFI) is }\end{array}$ & 289 & $\begin{array}{l}\text { Strongly } \\
\text { Agree }\end{array}$ \\
\hline 2 & $\begin{array}{l}\text { I can explain the } \\
\text { purpose of SFI }\end{array}$ & 291 & $\begin{array}{l}\text { Strongly } \\
\text { Agree }\end{array}$ \\
\hline 3 & $\begin{array}{l}\text { The Requirements to } \\
\text { become a SFI lecturer } \\
\text { can be met by a field } \\
\text { supervisor }\end{array}$ & 296 & $\begin{array}{l}\text { Strongly } \\
\text { Agree }\end{array}$ \\
\hline 4 & $\begin{array}{l}\text { The Requirements to } \\
\text { become a SFI civil } \\
\text { servant teacher can be } \\
\text { met by a civil servant } \\
\text { teacher }\end{array}$ & 294 & $\begin{array}{l}\text { Strongly } \\
\text { Agree }\end{array}$ \\
\hline 5 & $\begin{array}{l}\text { The Requirements to } \\
\text { become a SFI partner } \\
\text { school can be met by } \\
\text { partner schools }\end{array}$ & 304 & $\begin{array}{l}\text { Strongly } \\
\text { Agree }\end{array}$ \\
\hline 6 & $\begin{array}{l}\text { The Planning steps } \\
\text { listed in the guide are } \\
\text { confusing }\end{array}$ & 188 & $\begin{array}{l}\text { Don't } \\
\text { Agree }\end{array}$ \\
\hline 7 & $\begin{array}{l}\text { The steps for } \\
\text { implementing SFI can } \\
\text { be fulfilled by students }\end{array}$ & 282 & $\begin{array}{l}\text { Strongly } \\
\text { Agree }\end{array}$ \\
\hline 8 & $\begin{array}{l}\text { The Explanation on the } \\
\text { mentoring system has } \\
\text { not been fulfilled by } \\
\text { the lecturer }\end{array}$ & 194 & $\begin{array}{l}\text { Don't } \\
\text { Agree }\end{array}$ \\
\hline 9 & $\begin{array}{l}\text { The Explanation on the } \\
\text { mentoring system } \\
\text { needs to be } \\
\text { operationalized }\end{array}$ & 249 & Agree \\
\hline 10 & $\begin{array}{l}\text { The Explanation of the } \\
\text { assessment of the } \\
\text { worksheet needs to be } \\
\text { improved }\end{array}$ & 232 & Agree \\
\hline 11 & $\begin{array}{l}\text { The Explanation needs } \\
\text { to contain an } \\
\text { explanation of how the } \\
\text { value is assigned }\end{array}$ & 256 & Agree \\
\hline 12 & $\begin{array}{l}\text { The Explanation on the } \\
\text { management system is } \\
\text { easy to understand }\end{array}$ & 267 & Agree \\
\hline 13 & $\begin{array}{l}\text { The Explanation in the } \\
\text { financing section of the } \\
\text { guide needs to be } \\
\text { added }\end{array}$ & 252 & Agree \\
\hline
\end{tabular}




\begin{tabular}{|c|l|c|l}
\hline $\mathbf{1 4}$ & $\begin{array}{l}\text { The explanations } \\
\text { relating to quality } \\
\text { assurance need to be } \\
\text { clarified }\end{array}$ & 269 & $\begin{array}{l}\text { Strongly } \\
\text { Agree }\end{array}$ \\
\hline $\mathbf{1 5}$ & $\begin{array}{l}\text { The Explanation in the } \\
\text { study material section } \\
\text { is confusing }\end{array}$ & 201 & $\begin{array}{l}\text { Don't } \\
\text { Agree }\end{array}$ \\
\hline $\mathbf{1 6}$ & $\begin{array}{l}\text { The Study materials } \\
\text { can help students } \\
\text { understand their work } \\
\text { in PLP }\end{array}$ & $\begin{array}{l}\text { I already understand } \\
\text { the concept of } \\
\text { Technological } \\
\text { Pedagogical And } \\
\text { Content Knowledge } \\
\text { (TPACK) integrated in } \\
\text { AUD learning }\end{array}$ & $\begin{array}{l}\text { Strongly } \\
\text { Agree }\end{array}$ \\
\hline
\end{tabular}

The occurrence of differences in perception can be caused by an understanding of the perceived object [20]; [21].

\section{AUTHORS' CONTRIBUTIONS}

The authors have tried to pour all their abilities to present writings that are useful for the world of education, especially for improving the quality of educational services in ECE institutions and increasing the professionalism of ECE teachers from identifying problems, conducting research and writing articles. Hopefully this article will be meaningful for improving the quality of writers and organizing ECE in Indonesia, especially in Medan.

\section{ACKNOWLEDGMENTS}

This research was carried out with the moral and material support (UNIMED PNBP funds) allocated by the leadership of the Medan State University. To the Chancellor and Vice Chancellor of Unimed, the Dean and Vice Dean 1, 2 and 3 of the Faculty of Education, UNIMED, thank you for your help. The research team would also like to thank the leadership of LPPM Unimed along with the staff and reviewer team for the assistance and moral support provided. Especially to partner schools, the Salsa Kindergarten teachers as a discussion team about the implementation of teacher professionalism duties, we thank you for the input provided. Likewise, to Mr. and Mrs. Field supervisor lecturers (PGPAUD FIP Unimed lecturers) and Kindergarten teachers as tutors, we thank you. Hopefully this research can be used as input for improving the quality of ECE teachers.

\section{REFERENCES}

[1] Alhanifah. (2012). Pengertian dan Ciri Profesionalisme serta Kode Etik Profesi. [Online]: Tersedia:

http://Alhanafiah.wordpress.com/2012/04/02/penge rtian-dan-ciri-profesionalisme-serta-kode-etikprofesi

[2] Maiza, Z., \& Nurhafizah, N. (2019). Pengembangan Keprofesian Berkelanjutan dalam Meningkatkan Profesionalisme Guru Pendidikan Anak Usia Dini. Jurnal Obsesi : Jurnal Pendidikan Anak Usia Dini, $3(2)$,

356-365.

https://doi.org/10.31004/obsesi.v3i2.196

[3] Mena, Y., Supriyanto, A., \& Burhhanudin, B. (2016). Pelaksanaan Supervisi Klinis Dalam Meningkatkan Mutu Kinerja Guru Di Sekolah Dasar. Jurnal Pendidikan - Teori, Penelitian, Dan Pengembangan, 1(11), 21942199.https://doi.org/10.17977/jp.v1i11.8074

[4] Tanama, Y. J., Supriyanto, A., Universitas, M. P., \& Malang, N. (2016). Implementasi Supervisi Klinis Dalam. Jurnal Pendidikan: Teori, Penelitian, Dan Pengembangan, 1(11), 2231-2235. https://doi.org/http://dx.doi.org/10.17977/jp.v1i11. 8127

[5] Suyanto dan Asep Djihad, (2012). Bagaimana menjadi calon guru dan guru professional, Yogyakarta: Multi Presindo

[6] Irma Fitriyanti, Soewarto Hardhienata, dan Hari Muharam. (2019). Peningkatan komitmen profesi guru melalui pengembangan kepribadian dan pemberdayaan,. Jurnal Manajemen Pendidikan Vol.7, No.2, h. 808-815

[7] Case, K., Reagan, T., and Case, C. (2009). The Profesional Teacher. California: Jossey Bass.

[8] Brock, Avril. (2012). Building a Model of Early Years Profesionalism from Practitioners' Perspective. Journal of Early Childhood Research, 11 (1) 27-44, 2012

[9] Yus, A., Handayani, P.H., Srinahyanti. 2017. Analisis Dimensi Profesionalisme Guru PAUD dalam Materi Belajar dan Pembelajaran untuk Anak Usia Dini. Laporan Penelitian

[10] Dewi, I., \& Suryana, D. (2020). Analisis Evaluasi Kinerja Pendidik Pendidikan Anak Usia Dini di PAUD Al Azhar Bukittinggi. Jurnal Obsesi : Jurnal Pendidikan Anak Usia Dini, 4(2), 1051-1059. https://doi.org/10.31004/obsesi.v4i2.465

[11] Rosyati, T., Saprudin, S., \& Alaydrus, A. S. (2020). Kinerja OCB pada guru PAUD ditinjau dari 
Educational leadership dan Integritas. Jurnal Obsesi : Jurnal Pendidikan Anak Usia Dini, 5(1), 201-211. https://doi.org/10.31004/obsesi.v5i1.513

[12] Junanto, S., \& Kusna, N. A. A. (2018). Evaluasi Program Pembelajaran di PAUD Inklusi dengan Model Context, Input, Process, and Product (CIPP). Inklusi: Journal of Disability Studies, 5(2), 179194. https://doi.org/10.14421/ijds.050202

[13] Sum, T. A., \& Taran, E. G. M. (2020). Kompetensi Pedagogik Guru PAUD dalam Perencanaan dan Pelaksanaan Pembelajaran. Jurnal Obsesi : Jurnal Pendidikan Anak Usia Dini, 4 (2), 543-550. https://doi.org/10.31004/obsesi.v4i2.287

[14] Irma Fitriyanti, Soewarto Hardhienata, Hari Muharam. (2019). Peningkatan komitmen profesi guru melalui pengembangan kepribadian dan pemberdayaan, Jurnal Manajemen Pendidikan Vol.7, No.2

[15] Kamtini, Anita Yus, Nasriah, dan Salim,. (2020). Analisis pengembangan profesionalisme guru PAUD berdasarkan presfektif mahasiswa. Jurnal: Tematik Universitas Negeri Medan, Vol.10, No.3 (Desember 2020). h.184-191. https://jurnal.unimed.ac.id/2012/

[16] Sri Yuni Sulistiani, (2016). Pengaruh kemampuan kerja dan keterampilan kerja terhadap kinerja pegawai leasing, Jurnal Ekonologi, Vol 3, No 2. https://jurnal.unigal.ac.id/index.php/ekonologi/artic le/view/1148

[17] I Wayan Gede Indra Parta dan I Gede Aryana Mahayasa, (2021). Pengaruh Keterampilan Kerja, Team Work, dan Motivasi terhadap Kinerja Karyawan Bagian Produksi pada Art Shop Cahaya Silver di Celuk, Gianyar, Jurnal Manajemen, Kewirausahaan dan Pariwisata Pebruari 2021, Vol. 1 (No. 1): Hal 65-76

[18] Aan Subhan, (2017). Pengaruh kompetensi, kepuasan, kerja, dan komitmen organisasi terhadap kinerja guru (Studi pada SMK Negeri di Kota Tasikmalaya), Jurnal: Administrasi Pendidikan Jurnal Ilmiah Pascasarjana Vol 5 No.1https://jurnal.unigal.ac.id/index.php/adpen/arti cle/view/140

[19] Riris Anggun Cahyani, Ocky Sundari, dan Johnson Dongoran. (2020). Pengaruh komitmen organisasi dan kepuasan kerja terhadap kinerja karyawan (Studi Pada Perusahaan Daerah Air Minum (PDAM) Kota Salatiga), Jurnal: Ekobis Dewantara $\begin{array}{lll}\text { Vol. } & 3 & \text { No.1 }\end{array}$ https://media.neliti.com/media/publications/300113
[20] Meliza, Deri Wanto, Lukman Asha. (2020). Persepsi Masyarakat Sukaraja, Rejang Lebong Terhadap Edaran Menteri Agama Nomor: SE. 6. Tahun 2020 Mengenai Tata Cara beribadah Saat Pandemi, Jurnal Penelitian dan Pengabdian Masyarakat MANHAJ, Volume 9, Nomor https://ejournal.iainbengkulu.ac.id/index.php/manh aj

[21] Fahimul Amri, Shanti Nugroho Sulistyowati,. (2021). Analisis Persepsi Siswa Tentang Pembelajaran Yang Dilaksanakan Oleh Guru Dan Pengaruhnya Terhadap Kegiatan Belajar Siswa, Jurnal JEKPEND (Jurnal Ekonomi dan Pendidikan) Volume 4 Nomor Hal. 28-41, Homepage: http://ojs.unm.ac.id/JEKPEND 